\title{
Affluent adolescent girls of Delhi: eating and weight concerns
}

\author{
Ruchika Chugh* and Seema Puri \\ Department of Foods and Nutrition, Institute of Home Economics, Delhi University, NDSE-I, New Delhi-110049, India
}

(Received 8 June 2000 - Revised 3 May 2001 - Accepted 7 May 2001)

\begin{abstract}
Despite a dramatic increase in research on eating-related pathologies, gaps remain in our understanding of the factors responsible for the development and maintenance of dysfunctional attitudes and behaviour related to weight and eating among adolescents. A study was therefore conducted to compare eating and weight concerns among underweight, normal-weight and obese affluent adolescent girls in New Delhi. The sample comprised fifty underweight, fifty normalweight and thirty obese girls, 16-18 years of age. Information was collected about their body image perception, weight concerns and eating attitudes by a well-structured questionnaire. Dietary intake was determined by $24 \mathrm{~h}$ recall and a food-frequency questionnaire. Body size was adjudged by measurements of weight, height, waist, hip and mid upper arm circumferences, and the BMI and waist : hip ratio were determined. Of the subjects, $99.2 \%$ had a gynoid pattern of fat distribution. Concerns about excess weight were prevalent among the adolescent girls, even among those who were normal-weight and underweight. The level of satisfaction with body size decreased with increase in weight. Dieting behaviour was reported in a higher number of obese (76.6\%) compared with normal-weight (38\%) and underweight (14\%) girls. Of the obese girls, $43.3 \%$ were found to be at a significantly $(P=0.00109)$ greater risk of developing anorexia in the future. Characteristic dietary features of adolescence, such as missing meals, snacking and eating out, were observed. While the diets of most of the subjects were adequate in $\mathrm{Ca}$, thiamin, riboflavin and vitamin $\mathrm{C}$, they were found to be deficient in energy, protein, $\mathrm{Fe}$, niacin, vitamin $\mathrm{A}$ and fibre. Thus, it is important to recognize that weight concerns and dissatisfaction with body size may pose a threat to a healthy nutritional state, and may develop into precursors of a later eating disturbance.
\end{abstract}

Eating and weight concerns: Adolescent girls: India

Modern society encourages the search for the perfect body. Today's aesthetic ideal is a thin body, and now superimposed on this ideal is the need to be physically fit. This drive for fitness is mainly prevalent in adolescents and young adults; a high proportion of adolescents are trying to lose or gain weight or change their body proportion (Bull, 1998). Maturational physical changes place a heavier burden on female adolescents, who encounter thinness as a cultural standard of beauty for women (Streigel-Moore et al. 1986; Killen et al. 1992).

The persistent emphasis of our society on thinness and its characterization of obesity as unacceptable may predispose adolescents, especially young girls, towards distorted body image perceptions and induce dietary behaviour that may prove deleterious to their health. Unhealthy dieting behaviour and food habits such as omitting breakfast and frequent snacking are already prevalent among young adolescents, even among those who are not overweight (Brugman et al. 1997; Vatnani, 1998). A study carried out by Sadana et al. (1997) also revealed that 73.3 and $78.45 \%$ of girls of Jalandhar and Ludhiana cities respectively consumed fast foods. As these fast foods are consumed between meals, they reduce one's appetite for regular meals, so adolescents are more prone to nutritional problems than any other age group.

Recent surveys indicate that concern over body image and weight loss is common among the adolescent population, particularly girls, in Western countries (French et al. 1995; Brugman et al. 1997). This problem has now also assumed alarming proportions in India. Confirming the trend, there has been an increase in the number of cases of bulimia reported at one of the leading hospitals of New Delhi. Such extreme cases apart, approximately $50 \%$ of the teenage girls today are on what could easily be called a 'starvation diet', leading to anaemia, protein and $\mathrm{Ca}$ deficiency, hormonal imbalance and even amenorrhoea

\footnotetext{
Abbreviations: EAT, eating attitude test; NCHS, National Center for Health Statistics.

* Corresponding author: Ruchika Chugh, fax +91 11648 3561, email Ruchika.2.Chugh@sb.com
} 
(Bhagat, unpublished results). A recent study conducted by Gopalan (1998) revealed that the prevalence of obesity in middle-class urban Delhi was as high as $50 \%$ for females and $32 \%$ for males. Further, the National Nutrition Monitoring Bureau (1994) reported the prevalence of obesity among girls belonging to upper socio-economic strata as $28 \%$. The rapid growth of flourishing slimming establishments, particularly in the major cities in India, is an indicator of the increasing problem.

Understanding of body image perception, weight concerns, eating attitudes and the dietary behaviour of adolescent girls is becoming necessary for a number of reasons. First, unhealthy eating habits and attitudes and distorted body image perception may be a risk indicator for the development of eating disorders such as anorexia nervosa and bulimia nervosa (French \& Jeffery, 1994). There is general consensus that weight loss is a major symptom of anorexia nervosa (Casper \& Davis, 1977) and that repeated dieting appears to contribute to bulimia nervosa (Crisp, 1998). Both these disorders frequently begin during adolescence, as adolescents are often confused regarding what constitutes overweight, normal weight and underweight.

It has also been seen that abnormal eating behaviour or attitudes and distorted body perception in adolescents are associated with psycho-social and health behaviour problems such as tobacco use, emotional stress and school absence due to illness (French et al. 1995). Adolescents with unhealthy eating behaviour may also perform less well on demanding cognitive tasks than students with good eating habits (Rojers \& Green, 1993; Nelson et al. 1994). Epidemiological studies have also found a relationship between body weight fluctuation and CHD risk, as well as an increased risk of mortality and morbidity (Blair et al. 1993).

Few data are available on eating and weight concerns among teenagers in India. As this is a fast emerging problem, it was considered necessary to conduct the present study, which was undertaken to evaluate the differences, if any, in body image perception, weight concerns, eating attitudes and eating behaviour among underweight, normalweight and obese affluent adolescent girls.

\section{Methods}

\section{Study population}

A total of 150 affluent adolescent girls in the age group of 16-18 years attending a leading public school in Delhi were identified for the study. They were categorized into three groups, based on their BMI: obese; normal-weight; underweight. All underweight (fifty) and obese (thirty) girls were included in the study. As the number of subjects within the normal range was greater (seventy), a corresponding number (fifty) of normal-weight girls were selected by random sampling. The adolescent girls gave verbal consent to participating in the study. The subjects were familiarized with the objectives of the study and their queries about the survey were clarified.

\section{Data collection}

A suitable questionnaire was designed to elicit information regarding the general profile of the subjects including age, family composition and total family income; the health profile of the subjects included health problems, family history of diseases and the physical activity undertaken by the subjects and time spent on them.

A body image perception questionnaire (Wardle \& Marsland, 1990; Brownell \& Brunner, 1997) was used to assess the subjects' perception of the ideal body image, as it is useful for screening subjects with abnormal eating patterns. The questionnaires consist of pictures of men and women of ascending size and weight and related multiplechoice questions. The respondents were instructed to select the image that they found closest to their current size, that of the size they desired, their mother's typical size and their father's typical size. Subjects' responses were matched with the investigator's observations of their current size. Size judgements were made by the subjects selecting the one that they felt best applied to them from a list of five size descriptions from 'fat' to 'very thin' and five height descriptions from 'much too tall' to 'much too short'. The height descriptions were included principally to avoid too great a focus on weight. The subjects also rated their appraisal of four areas of the body (hips, thighs, stomach and chest) on a five-point scale from 'much too big' to 'much too small' and their body as a whole on a six-point scale from 'always satisfied' to 'never satisfied'. The body image perception questionnaire was analysed qualitatively and each item was examined individually.

An eating attitude test (EAT; Garner \& Garfinkel, 1979), used to detect subclinical cases of anorexia nervosa (abnormal preoccupation with weight and food intake) in the schoolgirl population, was used in the present study. From the original forty-item scale, thirty preliminary items were selected that reflected a range of reported anorexic behaviour and attitudes. The interview was designed to elicit detailed information about weight, menstruation and behaviour and attitudes towards food, eating, body shape, size and weight change. The questionnaire was analysed quantitatively. A cut-off score of 32 had been established for the forty-item EAT (Button \& Whitehouse, 1981) and was adapted to a score of 24 for the thirty-item EAT in the present study. Validation was carried out by pretesting the thirty-item questionnaire and comparing EAT scores of the same group of subjects on the thirty-item and forty-item questionnaires. Similar findings were reported on both.

A weight-cycling questionnaire developed by Brownell \& Brunner (1997) was used as a means of obtaining selfreport information on weight fluctuation and related concerns. The areas surveyed included body weight, dieting, weight change and weight fluctuation. The original questionnaire consisted of twenty-five multiple-choice items, of which thirteen were selected for the present study to avoid overlapping and to include those items that were culturally applicable. Pretesting was carried out before the questionnaire was administered. The results were examined qualitatively.

Dietary adequacy of the subjects was determined both quantitatively and qualitatively by a $24 \mathrm{~h}$ recall and 
food-frequency questionnaire, and by collecting information on eating habits such as frequency of eating out, omitting meals, snacking and pace of eating. The $24 \mathrm{~h}$ recall is simple, inexpensive and brief, making it a versatile tool for determining food intake. It requires little responsibility on the part of the respondents, but experienced well trained non-judgmental interviewers are essential for the administration, because specific information is needed about food intake. Disadvantages include the cost and administration time, the need to obtain multiple recalls to obtain a reliable estimate of the usual intake, participant burden and literacy demands in the estimate of portion sizes (Gibson, 1990). In the present study the subjects were asked to recall and describe all food and beverages they had consumed over the previous $24 \mathrm{~h}$. Time of intake, food description, amount of food and location where food was eaten were recorded. Various types of standardized utensils were used to assist in recalling and assessing the portion size of the food consumed. The subjects were also asked whether the intake was usual or different from the normal routine.

The food-frequency questionnaire has relatively lower administrative costs, requires less time and has the ability to assess the usual and longer-term intake; disadvantages include inaccuracy of absolute nutrient values, fluctuation of nutrient values depending on instrument length and structure, lack of detail regarding specific foods and general imprecision (Gibson, 1990). In the present study the foodfrequency questionnaire was used to find the frequency of consumption of various food items. The questionnaire included a list of commonly consumed foods, and the response options given included more than one food daily, once daily, two or three times weekly, once weekly, once fortnightly, once monthly or less. To limit overreporting, we removed the response categories of four and five times daily.

Since both the methods have certain advantages and disadvantages, a $1 \mathrm{~d} 24 \mathrm{~h}$ recall supported by the foodfrequency questionnaire was used to distinguish differences in intake between groups of underweight, normal-weight and obese subjects.

\section{Anthropometric measurements}

Anthropometry is especially important during adolescence, because it allows the monitoring of hormone-mediated changes in growth and maturation during this period. Moreover, because growth may be sensitive to nutritional deficit and surfeit, adolescent anthropometry provides indicators of nutritional and health risks that may be diagnostic of obesity (World Health Organization, 1995).

Weight was measured to the nearest $0 \cdot 1 \mathrm{~kg}$ with subjects in school uniform, with emptied pockets and without shoes. A precalibrated Krups scale (Dr Bel Ram \& Sons Ltd., New Delhi, India) with weighing capacity of $130 \mathrm{~kg}$ was used.

Height was measured without shoes to the nearest $1 \mathrm{~mm}$ by means of an 'anthropometric rod' with a steel tape joined

Table 1. General characteristics of the affluent adolescent female Indian subjects*

\begin{tabular}{|c|c|c|c|c|c|c|}
\hline \multirow[t]{2}{*}{ Group ... } & \multicolumn{2}{|c|}{$\begin{array}{l}\text { Obese } \\
(n 30)\end{array}$} & \multicolumn{2}{|c|}{$\begin{array}{l}\text { Normal- } \\
\text { weight } \\
\text { (n 50) }\end{array}$} & \multicolumn{2}{|c|}{$\begin{array}{l}\text { Underweight } \\
\qquad(n 50)\end{array}$} \\
\hline & $n$ & $\%$ & $n$ & $\%$ & $n$ & $\%$ \\
\hline BMI $\left(\mathrm{kg} / \mathrm{m}^{2}\right)$ & 30 & 20 & 70 & $46 \cdot 7$ & 50 & $33 \cdot 3$ \\
\hline \multicolumn{7}{|l|}{ Family size } \\
\hline 3 & 4 & $13 \cdot 3$ & 1 & 2 & 3 & 6 \\
\hline 4 & 16 & 53.0 & 26 & 52 & 23 & 46 \\
\hline 5 & 9 & $30 \cdot 0$ & 22 & 44 & 18 & 36 \\
\hline 6 & - & - & 1 & 2 & 4 & 8 \\
\hline 7 & 1 & 3.3 & - & - & 2 & 4 \\
\hline \multicolumn{7}{|l|}{ No. of earning members } \\
\hline 1 & 19 & 63.3 & 32 & 64 & 33 & 66 \\
\hline 2 & 8 & $26 \cdot 7$ & 17 & 34 & 14 & 28 \\
\hline 3 & 2 & $6 \cdot 7$ & 1 & 2 & 2 & 4 \\
\hline 4 & 1 & $3 \cdot 3$ & - & - & 1 & 2 \\
\hline \multicolumn{7}{|c|}{ Monthly family Income (Rs) } \\
\hline$<5000$ & 2 & $6 \cdot 7$ & - & - & 2 & 4 \\
\hline $5000-7000$ & 2 & $6 \cdot 7$ & 2 & 4 & 4 & 8 \\
\hline $7000-9000$ & 5 & $16 \cdot 7$ & 6 & 12 & 7 & 14 \\
\hline$>9000$ & 20 & $66 \cdot 7$ & 39 & 78 & 36 & 72 \\
\hline No response & 1 & 3.3 & 3 & 6 & 1 & 2 \\
\hline \multicolumn{7}{|l|}{ Family health profile† } \\
\hline Obesity & 12 & 40 & 4 & 8 & 3 & 6 \\
\hline Diabetes & 12 & 40 & 26 & 52 & 15 & 30 \\
\hline Hypertension & 11 & $36 \cdot 7$ & 11 & 22 & 13 & 26 \\
\hline Heart disease & 5 & $16 \cdot 7$ & 8 & 16 & 4 & 8 \\
\hline Respiratory disorder & - & - & 7 & 14 & 5 & 10 \\
\hline Hormonal disorder & 2 & $6 \cdot 7$ & 6 & 12 & 1 & 2 \\
\hline Others & 5 & $16 \cdot 6$ & 6 & 12 & 6 & 12 \\
\hline
\end{tabular}

${ }^{*}$ For details of subjects and procedures, see p. 536

† Several subjects had more than one family member suffering from several of the profile options. 
to a level platform. The index of adiposity used was the BMI. The classification (Garrow \& Websta, 1985) of the BMI categories was as follows: underweight, $<20 \mathrm{~kg} / \mathrm{m}^{2}$; normal weight, $20-24.9 \mathrm{~kg} / \mathrm{m}^{2}$; grade I obesity, $25-29.9 \mathrm{~kg} / \mathrm{m}^{2}$; grade II obesity, $30-40 \mathrm{~kg} / \mathrm{m}^{2}$; grade III obesity, $>40 \mathrm{~kg} / \mathrm{m}^{2}$.

Mid upper arm, waist and hip circumferences were taken with a non-stretchable polyvinyl chloride tape to the nearest $1 \mathrm{~mm}$. The waist:hip ratio as an indicator of cardiovascular and other diseases (diabetes, cancer, gallstones, hypertension, varicose veins) was also calculated.

\section{Data analysis}

The SPSS version 8.00 (SPSS Inc., Chicago, IL, USA) was used for data analysis. Frequency distribution was assessed and percentages were calculated for a number of variables. The $\chi^{2}$ test was used to assess the association between categorical variables. Significant differences between the anthropometric measurements and mean nutrient intake values was determined statistically by applying independent $t$ tests and group $t$ tests.

\section{Results}

Table 1 shows the general characteristics of the subjects. The prevalence of obesity among the subjects was found to be $20 \%$, with their BMI ranging between 25 and $34.6 \mathrm{~kg} / \mathrm{m}^{2}$. None of the obese subjects was grossly overweight. The majority of the subjects in all the three groups had a family size of four to five. In all the three categories about $64 \%$ of the subjects had one earning member in the family, indicating that the mothers of most of the subjects were housewives. On average, $73 \%$ of the subjects had a family income above Rs 9000 per month (approximately £144).

\section{Family health profile}

The prevalence of obesity among the family members was highest in the obese subjects $(40 \%)$ compared with the other two groups, and obesity was found to be more prevalent among mothers than fathers in the case of obese subjects. The prevalence of heart disease among the family members of obese and normal-weight subjects was about $16 \%$ compared with $8 \%$ in underweight subjects. About onequarter of the normal-weight subjects were suffering from respiratory or hormonal problems, followed by underweight $(12 \%)$ and obese $(6.7 \%)$ subjects. Other problems prevalent in the family members of all three groups were depression, skin disease, arthritis and sinusitus.

\section{Morbidity profile of subjects}

The morbidity profile of the subjects indicated that more than $75 \%$ of the subjects in all three groups had not suffered from any major ailment in the past year. Infective hepatitis, tonsillitis, asthma, typhoid, hormonal disorders and chronic fever were some of the illnesses reported in the rest of the subjects in the three groups.

\section{Physical activity}

In the present study more than $50 \%$ of the subjects did not undertake any form of exercise, with the percentage being highest (60) among the obese.

\section{Body image perception and weight concerns}

In the present study body image perception data revealed that a significant number $(P=0.00002)$ of adolescents perceived themselves to be heavier than they actually were, and hence wanted to be thinner. Besides the obese subjects, this perception was also recorded among the normal and underweight subjects. A significant number $(P=0 \cdot 0003)$ of underweight subjects $(52 \%)$ overestimated their body size.

A significant number $(P=0 \cdot 0007)$ of obese subjects were dissatisfied with their appearance; $96 \%$ of the obese subjects, $88 \%$ of the normal-weight and $42 \%$ of the underweight subjects were found to be dissatisfied with their present weight. While the majority of the obese subjects $(63.3 \%)$ wanted to lose more than $16 \mathrm{~kg}$, even subjects in the normal-weight $(88 \%)$ and underweight $(32 \%)$ groups wanted to lose between 5 and $16 \mathrm{~kg}$. A significant difference was seen among the responses given by the overweight, normal-weight and underweight girls regarding difficulty in maintaining weight. A significantly higher number of obese subjects found it difficult to maintain weight compared with normal-weight and underweight subjects $(P=0 \cdot 00001)$. The majority $(60 \%)$ of the obese subjects reported that they would weigh more if they did not restrict food intake as compared with $42 \%$ of normal-weight and only $24 \%$ of underweight subjects. The frequency of dieting was greater in obese subjects $(76.6 \%)$, but was also reported in normalweight (38\%) and underweight (14\%) subjects, with $13.3 \%$ of obese subjects being chronic dieters. In fact, $20 \%$ of obese and $46 \%$ of normal-weight subjects considered themselves to be 'yo-yo' dieters.

Table 2. Eating attitude test scores affluent adolescent female Indian subjects grouped according to $\mathrm{BMI}$ and classified according to risk of developing anorexic behaviour ${ }^{*}$

\begin{tabular}{|c|c|c|c|c|c|c|}
\hline \multirow{2}{*}{$\begin{array}{l}\text { Group ... } \\
\text { Classification }\end{array}$} & \multicolumn{2}{|c|}{$\begin{array}{l}\text { Obese } \\
(n 30)\end{array}$} & \multicolumn{2}{|c|}{$\begin{array}{l}\text { Normal-weight } \\
\qquad(n 50)\end{array}$} & \multicolumn{2}{|c|}{$\begin{array}{l}\text { Underweight } \\
\text { (n 50) }\end{array}$} \\
\hline & $n$ & $\%$ & $n$ & $\%$ & $n$ & $\%$ \\
\hline Normal (score <24) & 17 & $56 \cdot 7$ & 38 & 76 & 46 & 92 \\
\hline At risk (score $>24$ ) & 13 & $43 \cdot 3$ & 12 & 24 & 4 & 8 \\
\hline
\end{tabular}

* For details of subjects and procedures, see p. 536 and Table 1. 


\section{Eating attitudes}

Table 2 shows that obese subjects were at a significantly ( $P=0.00109)$ greater risk of developing anorexic behaviour as compared with their normal-weight and underweight counterparts.

\section{Diet and nutrient intake}

Of normal-weight subjects $92 \%$ indulged in snacking compared with $88 \%$ of underweight subjects and $83.3 \%$ of obese subjects. While most of the obese subjects $(66.7 \%)$ and normal-weight subjects (54\%) missed meals, even $38 \%$ of underweight subjects did so. It was noted that, although the subjects had an awareness about healthy eating behaviour and weight management, the actual practices were not always followed.

The $24 \mathrm{~h}$ dietary recall of the adolescent girls (shown in Table 3) indicates that, while the diets of most of the subjects were adequate in $\mathrm{Ca}$, thiamin, riboflavin and vitamin $\mathrm{C}$, they were found to be deficient in energy, protein, Fe, niacin, vitamin A and fibre. Obese and normalweight subjects were not able to meet even two-thirds of the requirements for energy. However, diets of the underweight subjects met two-thirds of the requirements for most of the nutrients except $\mathrm{Fe}$, niacin and fibre. Fat intake was high in all three groups. The difference in intake between the obese and underweight groups was found to be statistically significant $(P<0.005)$ for energy, protein, fat, vitamin $\mathrm{A}$, niacin and $\mathrm{Fe}$; between normal-weight and underweight groups it was statistically significant $(P<0.005)$ for energy, fat and thiamin. There was no significant difference in intake in the normal-weight and obese groups.

\section{Anthropometric assessment}

Table 4 shows the comparison between the anthropometric data of the present study with international and Indian data.

Table 3. Daily nutrient intakes of the affluent adolescent female Indian subjects (16-18 years)§

(Mean values, standard deviations and ranges)

\begin{tabular}{|c|c|c|c|c|c|}
\hline \multirow[b]{2}{*}{ Nutrients } & \multirow[b]{2}{*}{ Group } & \multirow[b]{2}{*}{ RDA } & \multicolumn{3}{|c|}{ Intakes } \\
\hline & & & Mean & SD & Range \\
\hline \multirow[t]{3}{*}{ Energy (kJ) } & Obese & 8611 & $4690^{*} \dagger$ & 1710 & $1960-10316$ \\
\hline & Normal-weight & & $5095^{\star} \ddagger$ & 1275 & $2546-9117$ \\
\hline & Underweight & & $6036^{*}$ & 1496 & $3177-9572$ \\
\hline \multirow[t]{3}{*}{ Protein (g) } & Obese & 63 & $36 \cdot 6^{*} \dagger$ & $9 \cdot 3$ & $16 \cdot 6-60 \cdot 0$ \\
\hline & Normal-weight & & $41 \cdot 3^{*}$ & $13 \cdot 0$ & $13 \cdot 2-74 \cdot 6$ \\
\hline & Underweight & & $44 \cdot 1^{*}$ & $13 \cdot 1$ & $15 \cdot 2-78 \cdot 6$ \\
\hline \multirow[t]{3}{*}{ Carbohydrate (g) } & Obese & & $141 \cdot 2$ & $46 \cdot 8$ & $47.8-231.5$ \\
\hline & Normal-weight & & $179 \cdot 0$ & $59 \cdot 4$ & $77 \cdot 3-411 \cdot 6$ \\
\hline & Underweight & & $200 \cdot 4$ & $58 \cdot 8$ & $111 \cdot 5-332 \cdot 2$ \\
\hline \multirow[t]{3}{*}{ Fats (g) } & Obese & 22 & $36 \cdot 0^{*} \dagger$ & $18 \cdot 8$ & $13 \cdot 8-102 \cdot 1$ \\
\hline & Normal-weight & & $37 \cdot 1^{\star} \ddagger$ & 11.8 & $11 \cdot 6-63 \cdot 1$ \\
\hline & Underweight & & $48 \cdot 8^{\star}$ & $18 \cdot 5$ & $21 \cdot 9-99.0$ \\
\hline \multirow[t]{3}{*}{$\mathrm{Ca}(\mathrm{mg})$} & Obese & 500 & 531.0 & $265 \cdot 6$ & $117 \cdot 9-1084.5$ \\
\hline & Normal-weight & & $548 \cdot 6^{*}$ & $232 \cdot 3$ & $124 \cdot 7-954 \cdot 1$ \\
\hline & Underweight & & $680 \cdot 0$ & $346 \cdot 5$ & $109 \cdot 2-2262 \cdot 7$ \\
\hline \multirow[t]{3}{*}{$\mathrm{Fe}(\mathrm{mg})$} & Obese & 30 & $8 \cdot 81^{*} \dagger$ & $2 \cdot 16$ & $4 \cdot 2-12 \cdot 9$ \\
\hline & Normal-weight & & $10 \cdot 11^{*}$ & $2 \cdot 82$ & $4 \cdot 5-19 \cdot 0$ \\
\hline & Underweight & & $10 \cdot 75^{\star}$ & 2.99 & $4 \cdot 8-18 \cdot 8$ \\
\hline \multirow[t]{3}{*}{ Thiamin (mg) } & Obese & $1 \cdot 0$ & 0.90 & 0.44 & $0.31-1.94$ \\
\hline & Normal-weight & & $0.86^{*} \ddagger$ & 0.30 & $0.27-1.64$ \\
\hline & Underweight & & $1.09^{\top}$ & 0.35 & $0.49-1.57$ \\
\hline \multirow{3}{*}{ Riboflavin (mg) } & Obese & $1 \cdot 2$ & $1 \cdot 10$ & 0.58 & $0.25-2.67$ \\
\hline & Normal-weight & & $1 \cdot 15 \dagger$ & 0.52 & $0.27-2 \cdot 81$ \\
\hline & Underweight & & $1.53^{\star}$ & 0.80 & $0.34-3 \cdot 31$ \\
\hline \multirow[t]{3}{*}{ Niacin (mg) } & Obese & 14 & $6 \cdot 68^{*} \dagger$ & $2 \cdot 31$ & $2 \cdot 81-11 \cdot 48$ \\
\hline & Normal-weight & & $8 \cdot 23^{*}$ & 2.77 & $3.83-15 \cdot 01$ \\
\hline & Underweight & & $8.98^{*}$ & 2.55 & $5 \cdot 24-15 \cdot 64$ \\
\hline \multirow[t]{3}{*}{ Vitamin A $(\mu \mathrm{g})$} & Obese & 600 & $361 \cdot 5^{\star} \dagger$ & 167.9 & $116 \cdot 3-846 \cdot 0$ \\
\hline & Normal-weight & & $381 \cdot 1^{*} \ddagger$ & $212 \cdot 7$ & $95 \cdot 6-1468 \cdot 0$ \\
\hline & Underweight & & $505 \cdot 9^{*}$ & $250 \cdot 9$ & $185 \cdot 1-1742 \cdot 9$ \\
\hline \multirow[t]{3}{*}{ Vitamin C (mg) } & Obese & 40 & $62 \cdot 6$ & 52.9 & $9 \cdot 7-193 \cdot 1$ \\
\hline & Normal-weight & & $48 \cdot 9$ & $38 \cdot 1$ & $10 \cdot 9-192 \cdot 8$ \\
\hline & Underweight & & $67 \cdot 5^{\star}$ & 51.3 & $9.3-197 \cdot 7$ \\
\hline \multirow[t]{3}{*}{ Fibre (g) } & Obese & & $4 \cdot 66$ & 1.72 & $1 \cdot 67-6 \cdot 98$ \\
\hline & Normal-weight & & 4.91 & $2 \cdot 43$ & $1.53-8.75$ \\
\hline & Underweight & & $6 \cdot 24$ & 3.08 & $2.25-10.54$ \\
\hline
\end{tabular}

RDA, recommended dietary allowances (Indian Council of Medical Research, 1990).

Mean values were significantly different from RDA values ( $t$ test): ${ }^{*} P<0.005$.

Mean values were significantly different of obese from those for underweight subjects $(t$ test): $† P<0.005$.

Mean values were significantly different of normal from those for underweight subjects $(t$ test): $¥ P<0.005$.

$\S$ For details of subjects and procedures, see p. 536 and Table 1. 
While the heights of the subjects were significantly $(P<0.005)$ lower than the National Center for Health Statistics (1977; NCHS) data, they were found to be higher than those of the Nutrition Foundation of India (1989) and Agarwal et al. (1992) data. The weights of the obese subjects were significantly $(P<0.005)$ higher than the NCHS data and the Indian data, whereas the weights of the underweight subjects were significantly lower $(P<0 \cdot 005)$ than the NCHS data and the Indian data. The weights of the normal-weight subjects were significantly lower $(P<0.005)$ than the NCHS data but higher than the Indian data. Differences were observed in waist, hip and mid upper arm circumferences of obese, normal-weight and underweight subjects, as shown in Table 5.

\section{Discussion}

The present study was based on a limited sample of affluent Delhi schoolgirls and therefore, the findings do not necessarily reflect general population trends. The present study found that most of the subjects in the three groups had a family income above Rs 9000 per month or Rs 108000 annually, indicating that they belonged to a fairly affluent background. The Indian Market Demographic Report (Natarajan, 1998) categorizes the high-income group as those people who have a family income above Rs 106000 annually.

Approximately one-third of the obese subjects reported the prevalence of obesity in their family, compared with only 8 and $5.9 \%$ of normal-weight and underweight subjects respectively. The high prevalence of obesity among family members of the obese subjects supports the findings of Stunkard et al. (1986), who concluded that fat parents tend to have fat children. Obesity was found to be more prevalent among mothers than fathers in the case of obese subjects, confirming the findings of an earlier study (Noble, 1997).

Lack of activity plays an important role in the development, progression and perpetuation of obesity in adolescence (Greenwood \& Richardson, 1979). Miller \& Binns (1979) reported that the problem of obese adolescents was not so much overeating as underexercising. This was also noted in the present study. An important reason for low levels of exercise could be academic pressure, as the subjects investigated were studying in school-leaving classes.

Research beginning in the early 1980s has generally found that adolescent girls are more dissatisfied with their bodies than adolescent boys (Thompson, 1990). Davies \& Furnham (1986) concluded in a study of British adolescent females that, while less than $4 \%$ of the sample were actually overweight, over $40 \%$ considered themselves to be overweight. In the present study also, $40 \%$ of the normalweight and $80 \%$ of the underweight subjects perceived themselves to be heavier than they actually were; $52 \%$ of the underweight subjects overestimated their body size, as did $28 \%$ of normal-weight subjects.

The level of satisfaction with appearance increased as weight decreased. The majority of the obese and normalweight subjects and $42 \%$ of the underweight subjects were dissatisfied with their present weight. Thus, the obese and normal-weight subjects showed greater concern for their weight. It was observed that obese and normal-weight subjects were keen to reduce weight. Surprisingly, even $32 \%$ of the underweight girls wanted to lose weight (between 5 and $16 \mathrm{~kg}$ ). Even though $58 \%$ of the underweight subjects were satisfied with their present weight, when asked if they desired to gain or change weight, all subjects replied in the affirmative. The results of the present study support those of Wardle \& Marsland (1990) who reported that $>50 \%$ of females were dissatisfied with their weight and wanted to lose weight. The extent of subjective body-image disturbance in the normal population has led Rodin et al. (1984) to coin the term 'normative discontent' to describe the degree of disturbance in asymptotic females. It is becoming clear that body image dysfunction exists even in the population with no reported eating disorders. The concern over weight and dissatisfaction with one's body has become so prevalent that it can be considered to be a normal part of female experience (Silberstein et al. 1987).

Of the obese subjects, $86.7 \%$ found it difficult to maintain weight, compared with $44 \%$ in the normal-weight group and only $28 \%$ in the underweight category, confirming the findings of the Reno Diet Heart Study,

Table 4. Comparison of anthropometric data with the National Center for Health Statistics (1977; NCHS) and Indian data (Nutrition Foundation of India, 1989 (NFI); (Agarwal et al. 1992)

\begin{tabular}{|c|c|c|c|c|c|c|}
\hline \multirow{2}{*}{$\frac{\text { Group }}{\text { Obese }}$} & \multirow{3}{*}{$\begin{array}{c}\begin{array}{c}\text { Age-group } \\
\text { (years and months) variable }\end{array} \\
160-1611 \\
170-1711\end{array}$} & \multicolumn{2}{|c|}{ Present study } & \multirow{2}{*}{$\begin{array}{r}\mathrm{NCHS} \\
1.63^{*}\end{array}$} & \multirow{2}{*}{$\frac{N F I}{1.58^{*}}$} & \multirow{2}{*}{$\frac{\text { Agarwal et al. }}{1.56^{\star}}$} \\
\hline & & Height (m) & 1.60 & & & \\
\hline & & & 1.59 & $1 \cdot 63^{*}$ & 1.58 & 1.57 \\
\hline \multirow[t]{2}{*}{ Normal-weight } & $160-1611$ & & 1.60 & $1.63^{*}$ & $1.58^{*}$ & $1.56^{*}$ \\
\hline & $170-1711$ & & 1.61 & $1.63^{*}$ & $1.58^{*}$ & $1.57^{*}$ \\
\hline \multirow[t]{2}{*}{ Underweight } & $160-1611$ & & 1.57 & $1.63^{*}$ & 1.58 & 1.56 \\
\hline & $170-1711$ & & 1.60 & $1.63^{*}$ & 1.58 & 1.57 \\
\hline \multirow[t]{2}{*}{ Obese } & $160-1611$ & Weight $(\mathrm{kg})$ & $70 \cdot 7$ & $57 \cdot 0^{\star}$ & $50 \cdot 2^{*}$ & $49 \cdot 2^{*}$ \\
\hline & $170-1711$ & & $67 \cdot 7$ & $57 \cdot 5^{\star}$ & $49 \cdot 7^{\star}$ & $49 \cdot 0^{*}$ \\
\hline \multirow[t]{2}{*}{ Normal-weight } & $160-1611$ & & 53.1 & $57 \cdot 0^{*}$ & $50 \cdot 2^{*}$ & $49 \cdot 2^{*}$ \\
\hline & $170-1711$ & & 53.4 & $57 \cdot 5^{\star}$ & $49 \cdot 7^{\star}$ & $49 \cdot 0^{*}$ \\
\hline \multirow[t]{2}{*}{ Underweight } & $160-1611$ & & $46 \cdot 4$ & $57 \cdot 0^{*}$ & $50 \cdot 2^{*}$ & $49 \cdot 2^{*}$ \\
\hline & $170-1711$ & & $46 \cdot 7$ & $57 \cdot 5^{\star}$ & $49 \cdot 7^{\star}$ & $49 \cdot 0^{*}$ \\
\hline
\end{tabular}

Mean values were significantly different from those for the present study $\left(t\right.$ test): ${ }^{*}<0.005$. 
which reported that a greater percentage of overweight subjects found it difficult to maintain weight compared with normal-weight subjects (Brownsell \& Brunner, 1997). The present study highlighted the fact that dieting in adolescents is practised by many who are not overweight. It can be said that dieting is a common practice among adolescent females. It is prevalent among those dissatisfied with their body size and is not confined to those who are actually overweight. The dieting adolescents are most clearly distinguished from non-dieting adolescents by their perception of being overweight and the feeling of body dissatisfaction and wanting to be thinner (Emmons, 1994).

Button \& Whitehouse (1981) reported that the EAT is a useful tool for detecting subclinical cases of anorexia nervosa, and that this characteristic may be identified among the underweight, the overweight, those of average weight and those whose weight is highly unstable. In the present study, $43.3 \%$ of the obese subjects scored high on the EAT compared with $24 \%$ of the normal-weight and $8 \%$ of the underweight subjects. Obese subjects were at a greater risk of developing disordered eating behaviour compared with normal-weight and underweight subjects. This factor was due mainly to societal pressures to be thin, and it appears in large part to arise from a widespread prejudice towards ideal female body weights at the lower end of the age-adjusted norms.

Characteristic dietary features of adolescence such as missing meals, eating out and snacking were observed among the subjects. The present investigation supports various studies that have concluded that snacking in addition to normal meals is common among adolescents (Beals et al. 1981; Cresswell et al. 1983; G Vatnani, unpublished results). Missing meals, commonly reported among adolescents, was also evident among the respondents in the present study; this finding supports those of Brugman et al. (1997) who reported that unhealthy food habits such as missing breakfast were present in young adolescents, even among those who were not overweight. Previous studies have shown that, while adolescent girls had adequate nutrition knowledge, this had little or no effect on their attitudes towards eating and fatness (Moses et al. 1989). This trend was also noted in the present study.

The diets of most of the subjects were adequate in $\mathrm{Ca}$, thiamin, riboflavin and vitamin $\mathrm{C}$, but they were found to be deficient in energy, protein, $\mathrm{Fe}$, niacin, vitamin $\mathrm{A}$ and fibre.
Kapoor \& Aneja (1992) and G Vatnani (unpublished results) in their studies on adolescent girls of Delhi have reported similar findings. Obese and normal-weight subjects were not able to meet even two-thirds of the requirements for energy. The low intakes may be due to dieting behaviour, which was prevalent in approximately two-thirds of the obese subjects and over one-third of the normal-weight subjects. Further, since intake values are systematically lower in the obese subjects, it could possibly be due to underreporting.

Anthropometric results indicated a slight difference in height among different weight groups and age groups. The mean height of the subjects was significantly $(P<0.005)$ lower than the NCHS standard, but higher than the Indian data. It was also found to be higher than those reported by S Kapoor (unpublished results) and Vatnani (1998). This finding supports the trend of increasing height which many developing countries are experiencing. A significant difference $(P<0.005)$ in weight was seen among the three groups. As the criteria of selection was the BMI, the difference was expected. As compared with the National Nutrition Monitoring Bureau (1991-2) reference value of $21.7 \mathrm{~cm}$ for Indians, the mid upper arm circumference in the present study was found to be higher for all the three groups. The pattern of fat distribution was gynoid in $99.2 \%$ of the subjects, indicating greater deposition of fat in the hip and gluteal region. The waist:hip ratio of the obese group $(0.7513$ (SD 0.039)) was found to be significantly $(P<0.005)$ higher than that of the normal-weight $(0 \cdot 7066$ (SD 0.30$))$ and underweight $(0.7024$ (SD 0.026)) groups, as also reported by $\mathrm{G}$ Vatnani (unpublished results).

Thus, it can be concluded that concerns about excess weight are prevalent among adolescent girls, even among normal-weight and underweight, which may predispose adolescents to unhealthy dietary behaviour that may have serious health consequences. It was observed that, although the adolescents had adequate knowledge, proper eating attitudes and practices were not being adopted. Thus, it is imperative to modify the ideal of 'thinness', which is propagated by the mass media, beauty pageants and the booming market of health clubs. What is especially needed is more accurate information about normal weight, normal changes in body composition and the importance of maintaining a healthy weight for optimal physical health during adolescence. Such information can be provided

Table 5. Data on selected anthropometric variables for affluent adolescent female Indian subjects $(16-18$ years)*

(Mean values and standard deviations, with the standard errors of the means)

\begin{tabular}{llcccc}
\hline Variable & Group & Mean & SD & Standard error & Median \\
\hline Mid upper arm circumference $(\mathrm{cm})$ & Obese & 30.6 & 0.79 & 0.14 & 30.48 \\
& Normal-weight & 25.6 & 0.84 & 0.12 & 25.4 \\
& Underweight & 22.9 & 0.58 & 0.08 & 22.86 \\
Waist circumference $(\mathrm{cm})$ & Obese & 33.4 & 2.56 & 0.47 & $32 \cdot 8$ \\
& Normal-weight & 27.8 & 1.85 & 0.26 & 27.8 \\
Hip circumference $(\mathrm{cm})$ & Underweight & 25.7 & 1.29 & 0.18 & 25.9 \\
& Obese & 44.2 & 2.88 & 0.53 & 43.0 \\
& Normal-weight & 39.1 & 1.97 & 0.28 & 39.0 \\
& Underweight & 36.3 & 1.35 & 0.19 & 36.0 \\
\hline
\end{tabular}

* For details of subjects and procedures, see p. 536 and Table 1. 
effectively through television, the Internet and print media, to which adolescents are exposed.

\section{References}

Agarwal DK, Agarwal KN, Upadhayay SK, Mittal R, Prakash R \& Rai S (1992) Physicial and sexual growth pattern of affluent Indian children from 5 to 18 years of age. Indian Pediatrics 29, $1203-1219$.

Beals TL, Anderson GH, Peterson RD, Thompson GW \& Hargreaves JA (1981) Between meals eating by Ontario children and teenagers. Journal of the Canadian Dietetic Association 42, 242-247.

Blair SN, Shaten J, Brownell KD, Collins G \& Lissner L (1993) Body weight change, all-cause mortality, and cause specific mortality in the multiple risk factor International Trial. Annals of Internal Medicine 119, 749-757.

Brownell KD \& Brunner RL (1992) Weight cycling questionnaire. In Obesity Assessment: Tools, Methods, Interpretations: A Reference Case: The Reno Diet Heart Study, 1st ed., pp. 561-569, 901-907 [ST St Joor, editor] New York, USA: Chapman \& Hall.

Brugman E, Meulmeester JF, Spee-van der Wekke A, Beuker RJ, Zaadstra BM, Radder JJ \& Verloove-Vanhorick PS (1997) Dieting, weight and health in adolescents in the Netherlands. International Journal of Obesity 21, 54-70.

Bull NL (1998) Studies of the dietary habits, food consumption and nutrient intake of adolescent and young adults. World Review of Nutrition and Dietetics 57, 24-74.

Button EJ \& Whitehouse A (1981) Subclinical anorexia nervosa. Psychological Medicine 11, 509-516.

Casper RC \& Davis JM (1977) On the course of anorexia nervosa. American Journal of Psychiatry 134, 974-978.

Cresswell J, Busby A, Young H \& Inglis V (1983) Dietary patterns of third-year secondary school girls in Glasgow. Human Nutrition and Applied Nutrition 37A, 301-306.

Crisp AH (1998) Some possible approaches to prevention of eating and body weight/shape disorders with particular reference to anorexia nervosa. International Journal of Eating Disorders 7, $1-7$.

Davies E \& Furnham A (1986) The dieting and body shape concerns of adolescent females. Journal of Child Psychology and Psychiatry and Allied Disciplines 27, 417-428.

Emmons L (1994) Predisposing factors differentiating adolescent dieters and non-dieters. Journal of the American Dietetic Association 94, 725-731.

French SA \& Jeffery RW (1994) Consequences of dieting to lose weight: Effects on physical and mental health. Health Psychology 13, 195-212.

French SA, Story M, Downes B, Resnick MD \& Blum RW (1995) Frequent dieting among adolescents: Psychosocial and health behavior correlates. American Journal of Public Health 85, 695-701.

Garner DM \& Garfinkel PE (1979) The eating attitude test: an index of the symptom of anorexia nervosa. Psychological Medicine 10, 647-656.

Garrow JS \& Websta J (1985) Quetelet index as a measure of fatness. International Journal of Obesity 9, 147-153.

Gibson RS (1990) Principles of Nutritional Assessment. New York: Oxford University Press.

Gopalan C (1998) Obesity in the Indian urban middle class. Nutrition Foundation of India Bulletin 19, 1-5.

Greenwood CT \& Richardson DP (1979) Nutrition during adolescence. World Review of Nutrition Dietetics 33, 1-41.

Indian Council of Medical Research (1990) Nutrient Requirement
\& Recommended Dietary Allowances for Indians. A Report of the Expert Group of the Indian Council of Medical Research, New Delhi: Indian Council of Medical Research.

Kapoor G \& Aneja S (1992) Nutritional disorders in adolescent girls. Adolescent Nutrition 29, 969-973.

Kapoor S (1995) A study of dietary adequacy, selected anthropometric variables and nutrition awareness of affluent school going adolescent girls (16-18 years). M Sc Dessertation, University of Delhi.

Killen JD, Hayard C, Litt I, Hammer LD, Wilson DM, Miner B, Taylor CB, Varady A \& Shisslak C (1992) Is puberty a risk factor for eating disorders? American Journal of Diseases of Children 146, 323-325.

Miller MR \& Binns CW (1979) Cultural differences in children's TV viewing habits and implication of nutritional status. Proceedings of the Nutrition Society 38, 120.

Moses N, Branilivy MM \& Lifshitz F (1989) Fear of obesity among adolescent girls. Pediatrics 83, 393-398.

Natarajan I (1998) Indian Market Demographic Report. New Delhi, India: National Council of Applied Economic Research.

National Center for Health Statistics (1977) Anthropometric Reference Data. Washington, DC: National Center for Health Statistics.

National Nutrition Monitoring Bureau (1991-2) Report of the Year (1994). Hyderabad: National Institute of Nutrition, Indian Council of Medical Research.

Nelson M, Bakaliou F \& Trivedi A (1994) Iron-deficiency anaemia and physical performance in adolescent girls from different ethnic backgrounds. British Journal of Nutrition 72, 427-433.

Noble RE (1997) The incidence of parental obesity in overweight individuals. International Journal of Eating Disorders 22, $265-271$.

Nutrition Foundation of India (1989) Growth of Affluent Indian Girls During Adolescence. Scientific Report no. 10. New Delhi: Nutrition Foundation of India.

Rodin J, Silberstein LR \& Streigel-Moore RH (1984) In Psychology and Gender, Nebraska Symposium on Motivation, pp. 267-307 [TB Sonderegger, editor]. Lincoln, NB: University of Nebraska Press.

Rogers PJ \& Green MW (1993) Dieting, dietary restraint and cognitive performance. British Journal of Clinical Psychology 32, $113-116$.

Sadana B, Khanna M \& Mann SK (1997) Consumption patterns of fast foods among teenagers. Applied Nutrition 22, 14-17.

Silberstein LR, Streigel-Moore RH \& Rodin J (1987) The Role of Shame in Symptom Formation pp. 89, 207 [HB Lewis, editor]. Hillsdale, NJ: Lawrence Erlbaum Associates.

Streigel-Moore RH, Silberstein LR \& Rodin J (1986) Toward an understanding of risk factors for bulimia. American Psychologist 412, 246-263.

Stunkard AJ, Foch TT \& Hrubec Z (1986) A twin study of human obesity. Journal of the American Medical Association 256, $51-54$.

Thompson JK (1990) Body Image Disturbance: Assessment and Treatment. Elmsford, NY: Pergamon Press.

Vatnani G (1998) Nutrition profile of obese vs non obese affluent adolescent girls (16-18 years). M Sc Dissertation, University of Delhi.

Wardle J \& Marsland L (1990) Adolescent concerns about weight and eating: A social development perspective. Journal of Psychosomatic Research 34, 371-391.

World Health Organization (1995) Physical Status: the Use and Interpretation of Anthropometry. Technical Report Series no. 854. Geneva: WHO. 